\author{
Barbara Ober-Domagalska \\ Uniwersytet Łódzki
}

\title{
PRZEMIANY W POSTAWACH ETYCZNYCH MŁODZIEŻY WOBEC PRACY
}

\begin{abstract}
Wstęp
Celem niniejszego artykułu jest prezentacja przemian w postawach młodzieży wobec pracy na przestrzeni ostatnich dwudziestu lat od momentu rozpoczęcia transformacji ustrojowej. Przegląd ten stanowi analiza wybranych artykułów. Ze względu na prezentowane w nich różne podejścia metodologiczne, w tym i różną precyzję metodologiczną, ten artykuł również należy traktować jako swoistą refleksję na temat zmiany owych postaw. Położenie akcentu na słowo refleksja nie oznacza jednak pozbawienia go jego naukowego charakteru. W niniejszym artykule odnoszę się do zaproponowanych koncepcji teoretycznych, które przedstawię poniżej.
\end{abstract}

\section{Przemiany w postawach wobec pracy - kontekst teoretyczny}

Początek refleksjom na temat różnic w postawach wobec pracy dał M. Weber, który zestawił ze sobą stworzone typy idealne człowieka doby feudalizmu i kapitalizmu. Pierwszy - homo religious, zorientowany jest na wartości religijne i duchowe, skoncentrowany na problemie zbawienia po śmierci pomija znaczenie dóbr materialnych, mogących oddalić go od możliwości zbawienia. Ten tradycyjny model jest hamulcem uniemożliwiającym prawidłowe funkcjonowanie w systemie kapitalistycznym [Weber: 1994: 41]. Drugi - idealny typ człowieka kapitalizmu, określany jest mianem homo oeconomicus. Jego głównym celem (celem samym w sobie) jest praca i potrzeba zarabiania pieniędzy [Weber: 1994: 52] i działanie zgodne z duchem kapitalizmu [Weber: 1994: 56]. Skupia się na wartościach materialnych i pomnażaniu zysku. Pomiędzy tymi dwoma typami idealnymi M. Weber umieścił, jako formę przejściową, człowieka kierującego 
się zasadami etyki protestanckiej. Cechą charakterystyczną takiego człowieka jest dbałość o wartości materialne, przy koncentracji na wartościach religijnych i moralnych [Nizińska: 1994: XVIII].

Koncepcji M. Webera, odwołującej się do specyficznych cech protestantów warunkujących ich pozytywne postawy wobec pracy, przeciwstawia się wielu badaczy. Koncepcja ta krytykowana jest zarówno od strony metodologicznej, logicznej jak i ideowej. Jednym z głównych krytyków jest M. Novak, który przeciwstawia się tezie Webera o uwarunkowanej wyznaniem protestanckim pozytywnej postawie wobec pracy. Autor ten uznaje, że osiaganie dzięki pracy zawodowej lepszego standardu życiowego nie jest niczym złym. Sprzeciwia się jednak nastawieniu na to by „mieć” zamiast „być” [Novak: 1993a: 203]. M. Novak formułuje jednak tezę mówiącą o związku pozytywnych postaw wobec pracy i budowy kapitalizmu z naukami Kościoła katolickiego. Jako przykład podaje nauki Jana Pawła II, który w kontekście wolności ekonomicznej wypunktował kreatywna subiektywność wolnego człowieka pracy, działającego w zgodzie z podstawowymi wartościami moralnymi [Novak: 1993a: 88]. M. Novak dostrzega również, że większość wolnych społeczeństw obywatelskich opiera się na trzech podstawowych systemach: (1) ekonomicznym, (2) politycznym, i (3) moralno-kulturowym [Novak: 1993b: 13]. Za najważniejszy z nich uznaje system moralno-kulturowy, który z historycznego punktu widzenia ma korzenie judeochrześcijańskie, odwołujące się do takich pojęć jak: „osoba ludzka” i ,wspólnota” [Novak: 1993b: 13].

Pojawia się zatem pytanie, która z prezentowanych koncepcji ma odzwierciedlenie $w$ realnych postawach ludzi wobec pracy i otoczenia instytucjonalnego: czy w dzisiejszych czasach kultury wyznaniowe nadal wywieraja decydujacy wptyw na postawy ekonomiczne $i$ standardy moralne? [Norris, Inglehart: 2006: 251]. R. Inglehart i C. Welzel analizując przemiany w wartościach współczesnego świata oparli się na teorii potrzeb A. Maslowa i wyszczególnili dwa czynniki, których wartość rozpościera się na wymiarach [Inglehart, Welzel: 2004]:

1) Przywiązanie do tradycji. Na jednym krańcu skali znajdują się wartości związane $\mathrm{z}$ afirmacją autorytetów i tradycyjnych instytucji, w tym rodziny i Kościoła, jako strażników religii, moralności oraz narodu. Na drugim biegunie znajdują się wartości świecko-racjonalne, którymi podkreśla się znaczenie jednostki i jej samorealizacji, poczucia niezależności i skuteczności.

2) Materializm vs. orientacja na potrzeby wyższego rzędu. Pierwszy wymiar charakteryzuje społeczeństwa rolnicze i przemysłowe, w których jednostki pragną zabezpieczyć podstawowe potrzeby związane z zapewnieniem przetrwania, bezpieczeństwa fizycznego i ekonomicznego. Druga orientacja charakteryzuje społeczeństwa postindustrialne, w których podstawowe potrzeby są już zabezpieczone. Jednostka może zatem skupić się na zaspokajaniu potrzeb wyższego rzędu takich jak potrzeba samorealizacji. 
Zaproponowane hipotezy zostały pozytywnie zweryfikowane i zaowocowały stworzeniem teorii modernizacji wartości [Norris, Inglehart: 2006], w której uwzględniono przemiany wartości związane z paradygmatem pracy. Inglehart zauważył, że dokonujący się rozwój społeczny prowadzi do zmian w obrębie postaw i wartości. Na ich podstawie przyjął, że nie religia warunkuje różnice w postawach w etosie pracy, lecz poziom rozwoju gospodarczego osiagany przez poszczególne narody. Jak podają na podstawie badań Inglehart i Norris, różnica między kulturami religijnymi staje się jaśniejsza, gdy za zmienną niezależną przy badaniu tych samych skal podstawimy typ społeczeństwa. Poziom etyki protestanckiej jest odwrotnie proporcjonalny do poziomu rozwoju gospodarczego. Bogate kraje postindustrialne prezentują najniższy poziom etyki protestanckiej, industrialne umiarkowany, a biedne - najwyższy. Kraje postindustrialne przywiązują najwyższą wagę dla czasu wolnego, relaksu i samorealizacji poza sferą zawodową. Autorzy twierdzą, że zależność ta wynika z faktu, że w krajach biednych praca jest niezbędnym elementem przeżycia człowieka, podczas gdy w krajach bogatych, w których rozwinięty jest system zabezpieczeń społecznych, stanowi ona wartość drugorzędną. Z powyższych analiz wynika, że istnieje większa różnica $\mathrm{w}$ poziomie etyki pracy pomiędzy społeczeństwami bogatymi a biednymi, niż pomiędzy społeczeństwami przynależącymi do odmiennych kultur religijnych [Norris, Inglehart: 2006: 236].

Model przemiany wartości zakłada, że w ponowoczesnym świecie normy i wartości ulegają gwałtownym przemianom [Mariański: 2001: 13]. W miejsce tradycyjnych norm i wartości tworzone są nowe - odzwierciedlające potrzeby współczesnego pluralistycznego świata. Na podobnym problemie skupił się również Z. Bauman, który prorokuje przemianę ,,paradygmatu pracy” w ,paradygmat konsumpcji”.

J. Mariański analizując przemianę społeczeństwa tradycyjnego w pluralistyczne wyszczególnił dokonujące się zmiany w wartościach, które mają charakter jednokierunkowy i przebiegają: od uniwersalizmu do partykularyzmu; od prospołeczności do egoizmu; od nieufności „,wymuszonej” do nieufności „wybranej”; od familiaryzmu do różnorodności życia małżeńskiego i rodzinnego; od poczucia odpowiedzialności do wartości samorozwojowych i związanych z tym: emancypacją, autonomizacją jednostki i krytycyzmem wobec autorytetów moralnych; od rygoryzmu do relatywizmu (liberalizmu moralnego) i permisywizmu [Mariański: 2008: 24-27].

J. Kopka zwraca z kolei uwagę na procesy mające wpływ na kształtowanie się moralnego porządku współczesnego świata ulegającego procesom globalizacji [Kopka: 2008: 61-62]:

- ekspansję centrów gospodarczych (państw, miast regionów), których celem jest tworzenie ponadnarodowych grup interesów, przynoszących nowe technologie i działających w celu zaspokojenia potrzeb konsumentów; 
- wprowadzenie nowych, zliberalizowanych form gospodarowania, które sprzyjają procesom demokratyzacji;

- zbliżanie się do siebie społeczeństw, na skutek rozprzestrzeniania się procesów komunikacji w wymiarze fizycznym (procesy integracyjne ułatwiające migrację obywateli) oraz w wymiarze wirtualnym, odnoszące się do rozprzestrzeniania się sieci powiązań drogą internetową;

- zmiany zachodzące na skutek formułowania się ponowoczesnej kultury nastawionej na: wielokulturowość, różnorodność, apoteozę wolności i rezygnację z wielkich narracji;

- demokratyzację życia publicznego związaną z koncentracją na podmiotowym traktowaniu jednostek, poszanowaniu ich praw oraz praw mniejszości. Wzrastający poziom edukacji wiedzy i aspiracji życiowych obywateli.

J. Kopka podkreśla, że zaprezentowane procesy wpływają na przemiany w sferze moralnej, w tym w prezentowanych wartościach, postawach i zachowaniach. Autorka twierdzi równocześnie, że tempo zachodzących procesów przyczynia się do koncentracji jednostek na wartościach pragmatycznych, które sprzyjaja zaspokojeniu potrzeb materialnych, a nie moralnych. Zachodzące przemiany pociągnęły za sobą zmianę w stosunku do tak zwanych autorytetów. Autorytetami przestali być przekazujący tradycyjne wartości i reguły działania, a stają się najlepiej dostosowani do „płynnej nowoczesności”, niosący zmiany [Kopka: 2008: 61-62].

Zachodzące $\mathrm{w}$ ponowoczesności przemiany określane są przez Ingleharta mianem postmodernistycznego przesunięcia wartości. W krajach zachodnich czynniki kulturowe mają większy wpływ na przemiany wartości niż czynniki ekonomiczne, co jest związane $\mathrm{z}$ wysokim poziomem życia $\mathrm{w}$ krajach postindustrialnych [Mariański: 2006: 280].

W kontekście oczekiwań biznesu co do jakości pracy sytuacja przedstawia się jednak inaczej. Z badań jakościowych przeprowadzonych przez L. Boltanskiego i E. Chiapello [Boltansky, Chiapello: 2002] wynika, że współczesny duch kapitalizmu uległ zmianie. Etos pracy narzuca na pracownika, by ten był gotowy na ciagłą zmianę warunków pracy i zamieszkania; innowacyjność i rywalizację. Współczesny pracownik działający zgodnie z duchem kapitalizmu ma być ekspertem, dla którego główną wartością jest praca. Powinien podejmować pracę na zlecenie, często od projektu do projektu, rezygnując ze stałego etatu. Jego główną dewizą powinna być ciągła nauka i umiejętność przekwalifikowywania się. Przyglądając się wyróżnionym przez Boltanskiego i Chiapello cechom można dojść do wniosku, że najlepiej współczesny etos pracy prezentują bohaterowie amerykańskich seriali korporacyjnych skupiających się na życiu zawodowym, w którym nie mam miejsca na sferę prywatną.

W opozycji do oczekiwań biznesu kształtują się postawy ludzi. Swadźba i Jacher formułują twierdzenie, ze w kontekście postaw i wartości wobec pracy zachodzą istotne zmiany. Na podstawie dokonanych przez siebie analiz dostrze- 
gają oni, że w ponowoczesnym świecie następuje spadek orientacji na osiagnięcia zawodowe i upadek etyki pracy. Autorzy akcentują, że zwiększa się znaczenie działań związanych z zaspokojeniem potrzeb wyższego rzędu, w tym znaczenie czasu wolnego [Swadźba, Jacher: 2008: 361-362].

Z. Bauman zwraca uwagę na fakt, że w dobie społeczeństwa przemysłowego pozostawanie bez pracy było odstępstwem od powszechnej normy społecznej i moralnej. Praca była źródłem kształtowania się tożsamości i samooceny [Bauman: 2006: 42]. Etyka pracy, zdaniem Z. Baumana, dzięki temu bezpośrednio przyczyniła się do ustanowienia nowoczesnego ustroju [ibidem: 46]. Społeczeństwo produkcyjne oparte było na angażowaniu ludzi w pracę i produkcję. Teraźniejsze, ponowoczesne społeczeństwo angażuje swoich członków w konsumpcję [ibidem: 54-55].

Podstawą bytu społeczeństwa konsumenckiego jest możliwość dokonywania wyborów. Możliwość ta stanowi metawartość ułatwiającą realizację wszystkich innych wartości. Antywartością jest natomiast niemożność dokonania wyboru.

W modernizmie jednostka, która raz nabyła tożsamość zachowywała ją przez całe życie. W ponowoczesności budowanie zaprojektowanej a priori tożsamości, zaplanowane na całe życie, może rodzić poważne trudności [ibidem: 61]. A jak twierdził E. Fromm, potrzeba integracji osobowości i poczucia tożsamości jest niezmiernie ważna, aczkolwiek trudna do zaspokojenia [Fromm: 1990]. Z. Bauman porównuje tożsamość ponowoczesnego człowieka do dobra konsumpcyjnego. Należy je bowiem posiąść, a następnie pozwolić zniknąć [Bauman: 2006: 63]. Człowiek pracy również winien koncentrować się na temporalności, elastyczności i konieczności ciagłej zmiany niczym w kalejdoskopie [Bauman: 1994: 16]. Podobną tezę formułuje R. Sonnett, którego zdaniem zmienił się charakter cech, które ułatwiają ludziom przystosowanie się do nowego kapitalizmu. Już nie ciężka praca i dyscyplina lecz gotowość do zmian i chęć podejmowania ryzyka są cechami istotnymi. Autor stawia tezę, która odpowiada założeniom Z. Baumana. Uważa mianowicie, że współczesna etyka nastawiona jest na powierzchowność, teraźniejszość i pozorność. Cechy tak istotne dla etyki protestanckiej jak solidność i przewidywalność odchodzą natomiast do lamusa [Sonet: 2006: 147].

D. Walczak-Duraj formułuje opinię, ze w społeczeństwach zachodnich nabywanie nowej tożsamości (grupowej, zawodowej, klasowej) ma związek z nabywaniem jej poprzez zachowania konsumenckie [Walczak-Duraj: 2008: 83]. Człowiek żyjący w społeczeństwie konsumpcyjnym nie potrafi odraczać gratyfikacji, tak jak robił to człowiek w erze produkcji [Bauman: 2006: 66]. W dobie konsumpcji nie są istotne wartości etyczne lecz estetyczne. To one bowiem integrują społeczeństwo konsumentów. Nastąpiło zatem przejście od etyki pracy do estetyki konsumpcji [ibidem: 68-70]. 
W dobie etyki pracy człowiek, bez względu na wypełniane przez niego zawody, był wobec zasad obowiązujących społecznie równy. W dobie społeczeństwa konsumpcyjnego wolność wyboru, mobilność i przede wszystkim estetyczna wartość pracy stała się narzędziem stratyfikacji społecznej [ibidem: 70-71]. Estetyka ta ma wpływ na to, że praca stała się narzędziem pożądanym. Dobra, pożądana w sensie estetycznym praca stała się przywilejem. Nie brakuje zatem ludzi, którzy pracują bez przerwy. Jednak w przeciwieństwie do społeczeństwa produkcyjnego wywodzą się oni z elit [ibidem: 72]. Jak podkreśla Z. Bauman: Uwolnienie pracy od skoncentrowanych na rynku kalkulacji i ograniczeń jakie one narzucaja wymagatoby zastapienia etyki pracy, ukształtowanej $w$ stużbie rynku pracy, etyka fachowości [ibidem: 207].

Niniejsze refleksje skłaniają do myślenia, że w sferze postaw wobec pracy nastapiły istotne zmiany. Zmiany te w kontekście tworzenia się nowego ładu ekonomicznego nazwane zostały przez D. Walczak-Duraj kontrideologią pracy i oznaczać mają zdaniem tej autorki wszelkie wartości, postawy, normy i zachowania, które pomimo swojej wewnętrznej niespójności oznaczają deprecjację pracy jako wartości [Walczak-Duraj: 2005]. Następuje odejście od tradycyjnego etosu pracy związanego z poczuciem obowiązku, dyscypliną, punktualnością, porządkiem i posłuszeństwem. Zaczynają dominować wartości konsumpcyjno-hedonistyczne oraz indywidualistyczne. W ponowoczesnym świecie praca staje się koniecznością by realizować ważniejsze cele życiowe [Jacher, Swadźba: 2008: 362].

Zmiany te mogły zatem dotknąc i postaw młodzieży, która na przestrzeni ostatnich dwudziestu lat dorastała w zmieniającej się Polsce. W sensie gospodarczym z kraju o gospodarce centralnie planowanej, przeszliśmy przez etap „dzikiego kapitalizmu” ostatnio stając się jednym z najlepiej rozwijających się krajów nowej, rozszerzonej Europy. W sensie propagowanych norm i wartości przeszliśmy z spolaryzowanego świata wartości propagowanych z jednej strony przez partię, z drugiej zaś przez Kościół katolicki.

Na kształtowanie się nowego etosu pracy wskazuje u młodzieży również Jacher i Swadźba. Dostrzegają oni że młodzież oprócz zapewnienia potrzeb egzystencjalnych oczekuje, że praca zawodowa da im satysfakcję i pomoże zrealizować się w innych sferach. W związku z tym autorzy mówią o istniejącej zmianie pokoleniowej i kształtowaniu się nowego etosu pracy będącego synonimem zmiany całego systemu wartości młodzieży [ibidem: 374$]$.

Jak zatem kształtują się postawy polskiej młodzieży wkraczającej na rynek pracy w okresie ostatnich dwudziestu lat transformacji? Wśród socjologów pojawiały się obawy, że polska młodzież, podobnie jak i całe społeczeństwo przestanie orientować się na wartości propagujące ład moralny [Kwieciński: 1990: 69-71]. K. Pawlina dopatrywał się w moralności młodzieży postaw idących w kierunku subiektywizacji norm, oraz szeroko pojętego relatywizmu [Pawlina: 1998: 53-63]. H. Świda-Ziemba zajęła się z kolei problemem permisywności 
u młodzieży. Na podstawie dokonanych analiz autorka stwierdza, że młodzież prezentuje raczej permisywizm niż relatywizm moralny, czy nihilizm. Postawa permisywna na poziomie abstrakcyjnym uznaje uniwersalność zasad moralnych. Towarzyszy temu jednak akceptacja nieprzestrzegania tych zasad przez ludzi w pewnych sytuacjach przez co normy moralne tracą moc regulacyjna. Nie następuje zwrot ku nihilizmowi moralnemu, a ranga moralności w świadomości młodzieży wzrasta. Jej badania wskazują również, że młodzież opisuje się jako pozbawiona zasad moralnych, choć indywidualne opinie na swój temat ma zdecydowanie odmienne. Autorka uważa, że przyczyną tego może być deklarowanie innych wartości niż faktyczna realizacja. Młodzież obserwując swoje pokolenie ocenia bowiem realne zachowania, a nie deklaracje składane przez indywidualne jednostki pod swoim adresem. Autorka stawia również tezę, ze młodzież może po prostu siebie nie znać [Świda-Ziemba: 2005: 14-35 i 2008: 146-148]. H. Świda-Zieba pisze o dwóch istniejących obok siebie światach, w których młodzież uczestniczy: publicznym i prywatnym. W światach tych funkcjonują inne normy moralne. Co dozwolone jest w jednym nie funkcjonuje w drugim. Młody człowiek musi jednak sprawnie miedzy nimi funkcjonować i się do nich dostosowywać [Świda-Ziemba: 2008: 154]. Również K. Kiciński formułuje obawę, że określone zasady uniwersalne moga przestać pełnić w przyszłości formę regulatorów życia zbiorowego i drogowskazów dla życia indywidualnego [Kiciński: 2002: 376]. R. Boguszewski formułuje z kolei tezę, że pomimo dającej się dostrzec relatywizacji norm moralnych i ucieczki przed pryncypializmem można jednak postrzegać postawy młodzieży jako przejaw temporalnej refleksyjności, a nie odrzucenia znanych norm i wartości [Boguszewski: 2009].

T. Borkowski przywołuje główne zasady „etyki” pracownika PRL’u, który kierował się W swoich postępowaniach ,specyficzną" logiką. Gdy robotnik kradł, to dlatego, że musiał, a nie chciał. Musiał, bo kradzionego towaru nie można było dostać w sposób legalny. Zachowanie takie miało świadczyć o znajomości norm etycznych (piętnie niezmiennych norm etycznych), przy równoczesnej tendencji do usprawiedliwiania łamania tych norm (piętno zmienności norm). Na negatywne postawy pracownika PRL miały również wpływ: pewność zatrudnienia i brak związku zarobków z efektywnością (czy się stoi czy się leży tysiac złotych się należy). Niemożność zwolnienia pracownika z pracy, powodowała, że pracownicy średniego szczebla chcąc wyrobić założone odgórnie normy pracy tolerowali zachowania nieetyczne: wykonywanie ,fuch” w czasie pracy, wykorzystywanie sprzętów i materiałów zakładowych w celach prywatnych, czy picie alkoholu. Wszystkie powyższe działania miały się również przyczyniać do masowego łapówkarstwa w PRL'u [Borkowski: 1999: 127-128].

Z badań prowadzonych przez D. Walczak-Duraj w 1993 r. wynika, że ponad $40 \%$ młodzieży szkół średnich (o profilach zawodowych) nie miała sprecyzowanych planów zawodowych. Ponad $18 \%$ młodych myślało o samozatrudnieniu. Prawie $16 \%$ myślało o pracy w kategoriach środka dającego zarobek. Taki 
sam odsetek chciał jednak w przyszłości podjąć pracę dającą zadowolenie. Jedynie 6\% młodych przypuszczało, że będzie musiało w przyszłości przekwalifikowywać się. Wśród czynników warunkujących osiagnięcie przez ludzi dobrych warunków materialnych badana w 1993 r. młodzież wymieniała prowadzenie własnego interesu (prawie 82\%), prace za granicą (72\%), zdolności i talent (65\%), pracę w prywatnym przedsiębiorstwie (40\%). Jedynie dla 32\% rzetelna i uczciwa praca w zawodzie była gwarantem osiagnięcia dobrych warunków materialnych. W badaniach D. Walczak-Duraj z 1993 r. praca miała charakter instrumentalny dla połowy badanej młodzieży. Na jej heteroteliczność wskazywał co czwarty badany młody człowiek. Jedynie co piąta badana osoba widziała w pracy aspekt autoteliczny. Jednak dla co 10 badanego praca była postrzegana jako zło konieczne [Duraj: 1993: 23]. Z tych samych badań wyłania się obraz „dobrego pracownika” nakreślony przez ówczesną młodzież. Jest nim dla większości (68\%) osoba dobrze wykonująca swoją pracę: rzetelna i solidna. Dla prawie 33\% badanych to również osoba obowiązkowa, zdyscyplinowana i sumienna. Co piąty uważa, że jest to osobna wydajna a dla $16 \%$ po prostu lubiąca swoją pracę. Mniej niż 15\% ankietowanych podkreślało w ocenie dobroci pracownika jego kompetencje interpersonalne, czy kwalifikacje. $Z$ niniejszego opisu wynika, że zdaniem badanej w 1993 r. młodzieży za istotne w ocenie pracy jest jej jakość a nie wydajność [ibidem: 28]. Co można uznać za pewnego rodzaju paradoks zważywszy na fakt, że ówczesnym pracownikom narzucano normy wydajności. Za główną przyczynę źle wykonywanej pracy obarczała badana młodzież zbyt niskie zarobki (70\%). Jednak już co drugi badany dopatrywał się w cechach indywidualnych każdego pracownika przyczyn owych nieprawidłowości [ibidem: 35].

D. Walczak-Duraj pytała również młodzież o to jak jej zdaniem procesy transformacyjne wpłyną na postawy Polaków wobec pracy zawodowej. Ponad połowa odpowiedziała, że nastapią zmiany w owych postawach. Co czwarty badany młody człowiek twierdził, że w związku z groźbą pojawienia się bezrobocia ludzie będą lepiej pracowali. Praca będzie lepiej traktowana, pracownicy bardziej będą dbać o jakość jej wykonania i wydajność. Polepszenie jakości pracy będzie również skutkiem wyższych zarobków.

Analizując przedstawione przez D. Walczak-Duraj opinie młodzieży o pracy zawodowej wyłania nam się obraz spójny z teorią modernizacji zaproponowaną przez Ingelharta. Polska młodzież wychowana w społeczne przemysłowym w swoich refleksjach na temat pracy i jej jakości prezentowanej przez pracowników określała ją w kategoriach instrumentalnych, jako środek zaspokojenia podstawowych potrzeb człowieka.

Zgodnie z przewidywaniami młodzieży badanej w 1993 r. przez D. Walczak-Duraj transformacja ustrojowa zmieniała postawy Polaków wobec pracy. Polacy zaczęli bardziej przykładać się do wykonywanej pracy, znikł lekceważący stosunek do niej. Nagły wzrost bezrobocia (nawet do 25\% w latach 2000- 
2004) spowodował, że praca zaczęła być postrzegana w kategoriach dobra najwyższego, które trzeba szanować. W pewnych obszarach można powiedzieć, że przeszliśmy ze skrajności w skrajność. W momencie najwyższego bezrobocia, powszechne było przyjmowanie młodych pracowników na tak zwane ,staże”, na których pracując w pełnym wymiarze godzin otrzymywano zasiłek z urzędu pracy w wysokości 400 zł. Alternatywą była praca „na czarno”, 7 dni w tygodniu za 600 zł.

B. Wciórka zebrała dane dotyczące wskaźnika wakacyjnej aktywności zawodowej młodzieży. Z danych tych wynika, że począwszy od 1992 do 2009 r. systematycznie rosła ilość gospodarstw, w których młodzież podejmowała pracę zarobkową podczas wakacji. Liczba ta wzrosła z 9\% do około 31\% w roku ubiegłym [Wciórka: 2009]. Ma to niemałe znaczenie w kontekście przyszłej pracy zawodowej. Podejmowanie dorywczej pracy kształtuje bowiem w młodzieży bardziej pozytywną i otwartą postawę do podejmowanej w przyszłości pracy. Młodzież jest bardziej otwarta na chęć samozatrudnienia oraz charakteryzuje się mniejszym lękiem o pozostanie bez pracy [Strzeszewski: 2000]. Z kolei z badań sondażowych przeprowadzonych na zlecenie „Gazety Wyborczej” przez firmę SMG/KRC na młodzieży w wieku 19-26 lat wynika, że prawie 80\% młodzieży podejmowało już różnego rodzaju pracę zarobkową. Prawie co czwarty ankietowany pracuje i uczy się równocześnie. Zdaniem autorów raportu młodzież jest coraz bardziej aktywna. Praca stała się wartością cenioną, o którą trzeba się postarać. Młodzi mają świadomość, że wykształcenie i znajomość języków obcych to już mało by zaskoczyć pracodawcę. Od przyszłej pracy młodzi oczekują, że będzie ciekawa. Młodzież chciałaby również by atmosfera w pracy była przyjazna. Młodzież chce również dobrze zarabiać, ale nie za cenę niezależności i poczucia wolności [www.egospodarka.pl].

Młodzież końca lat dziewięćdziesiątych, charakteryzowała się dużą potrzebą posiadania dóbr materialnych: chęć posiadania własnego samochodu, czy mieszkania była najczęściej wymienianym dobrem dla ponad połowy ankietowanych. Młodzież badana w tym okresie miała stabilną hierarchię celów i wartości. Za najważniejsze uznawała posiadanie rodziny (57\% wskazań) oraz posiadanie ciekawej, zgodnej z zainteresowaniami pracy (42\%). Kariera stała się celem dla co trzeciego badanego. Spadła natomiast potrzeba poczucia niezależności w pracy zawodowej z 10\% do 6\% (w porównaniu z rokiem 1994) [Sęk: 1999].

Na to samo pytanie zadane młodzieży w 2006 r. młodzież odpowiadała jeszcze bardziej stanowczo. Szczęście rodzinne stało się najistotniejszą wartością dla $72 \%$ ankietowanych. Praca również stanowi najwyżej cenioną wartość dla co drugiego badanego młodego Polaka. Można zatem zaobserwować wzrost znaczenia owych wartości dla pokolenia młodzieży [Boguszewski: 2006].

Ciekawe badania nad etyką produktywności (odp. protestanckiego etosu pracy) na polskiej młodzieży prowadziła A. Bronowicka i jej magistranci. Ponad 
40\% badanych studentów jest zdania, że ciężka praca daje szansę na dobre życie. Jednocześnie badani uważali, że każdy człowiek powinien mieć więcej wolnego czasu i nie powinien go poświęcać jedynie na pracę. Pomimo tego, zdaniem autorki, badaną grupe charakteryzuje wysoki poziom protestanckiej etyki pracy [Bronowicka: 2009: 90-91]. Wnioski z badań Bronowickiej pokrywają się zatem z tymi płynącymi z raportów CBOS przedstawionych m. in. przez A. Sęka.

W tym kontekście warto zwrócić uwagę na wyniki badań prowadzone na dorosłych, pracujących Polakach. M. Falkowska zwraca uwagę na fakt, że w toku transformacji Polacy zrewidowali swój pogląd na temat pracy i jej wartości [Falkowska: 1997]. Zdaniem B. Wciórki praca stała się wysoce cenioną wartością. Miały na to wpływ wzrost zagrożenia bezrobociem oraz wzrost znaczenia pracy wymagającej wysokich kompetencji i kwalifikacji. Autorka, w toku przeprowadzonych analiz wyodrębniła dwa czynniki określające postawy Polaków wobec pracy. Pierwszy czynnik - saomeralizacyjny - określa, w jakim stopniu praca zapewnia satysfakcje w wymiarze autotelicznym. Drugi - czynnik bezpieczeństwa pracowniczego, określa $\mathrm{w}$ jakim stopniu zaspokojone są podstawowe potrzeby pracownika [Wciórka: 1998]. Z dokonanych analiz wynika, że nastąpiły zmiany w poczuciu samorealizacji wynikającej z pracy dopiero w roku 1997. Podobne postawy zostały wyodrębnione $\mathrm{w}$ toku analiz dokonanych przez R. Boguszewskiego, który wyszczególnił postawę etosową (praca jest wartością samą w sobie) oraz pragmatyczną (praca jako sposób na zdobycie środków do życia). Jak zaznacza R. Boguszewski, pierwsza postawa jest bardziej charakterystyczna dla ludzi młodych, lepiej wykształconych i dobrze zarabiających. Jednak druga z prezentowanych postaw, mówiąca o roszczeniowych podejściu do pracy, jest bardzo typowa dla społeczeństwa polskiego, niezależnie od kategorii społeczno-demograficznych [Boguszewski: 2006].

W roku 1999 badania ankietowe na temat postrzegania norm etycznych przez studentów kierunków ekonomicznych (19-29 lat) przeprowadziła D. Kopycińska [Kopycińska: 1999: 205-216]. Autorka badała studentów, którzy mieli różny status zawodowy (od bezrobotnego do właściciela firmy) i choć badania nie były reprezentatywne dla kraju, ich wyniki wydają się niezmiernie ciekawe. Studenci reprezentujący grupę właścicieli firm zdecydowanie częściej akceptowali zachowania nieetyczne szeroko rozumianego pracodawcy, nie akceptując równocześnie zachowań nieetycznych ze strony pracownika. Wśród osób zatrudnionych sytuacja miała tendencję odwrotna. Najgorsze postawy prezentowali pracujący w firmach państwowych oraz bezrobotni. Z badań wynika, ze grupa osób, która najbardziej akceptuje normy etyczne są pracownicy zatrudnieni w firmach prywatnych.

W latach 1995-1998 W. Gasparski przeprowadził badania o charakterze jakościowym, z których wynika, że młodzież dostrzegała dużą tolerancje dla zachowań nieetycznych. Młodzież dostrzegała, że konflikty etyczne pojawiające się w życiu gospodarczym dotyczą nie tylko przedsiębiorstw, firm czy spótek 
jako catości; dotyczy on także osób działajacych w firmach i firm, w których pracuja [Gasparski: 2007: 104-108].

Z przeprowadzonych przeze mnie w $2006 \mathrm{r}$. badań na losowej grupie młodzieży licealnej wynika, że ma ona bardzo wysokie oczekiwania wobec zachowań etycznych pracowników. Młodzi bardziej akceptują, gdy pracownik daje prezenty niż je przyjmuje. Uważają, że pracownik nie może nadmiernie zużywać materiałów biurowych i powinien dbać o rzeczy firmy jak o swoją własność. Pomimo braku akceptacji dla kontroli komputerów służbowych pracownika młodzież oczekuje od pracowników przestrzegania norm obyczajowych w zakresie odwiedzania $w$ pracy stron związanych $\mathrm{z}$ hazardem, czy erotyką. Jednocześnie zgadza się z opinią, że korzystanie z komunikatorów internetowych w celach prywatnych powinno być zakazane. Badana młodzież uważa, że raczej nie powinno się zakazywać rozmów na tematy zawodowe poza miejscem pracy. Akceptowane są rozmowy z rodziną. Młodzi Polacy częściej wyrzuciliby niekulturalnego pracownika z pracy, niż pracowaliby nad nim, kierując go na szkolenia. Młodzi cenią lojalność wobec firmy. Twierdzą, że pracownicy powinni być zobowiązani do pracy tylko $\mathrm{w}$ jednej firmie, tak by uniknąć sprzeczności interesów. Odwołując się do możliwości podjęcia pracy w dwóch konkurencyjnych firmach, młodzież dopuszcza ją w przypadku trudnej sytuacji finansowej pracownika. Licealiści nie akceptują przychodzenia do pracy na kacu oraz spożywania różnego rodzaju środków psychoaktywnych [Ober-Domagalska: 2008: 88-102]. Ta sama młodzież zapytana o to jak sama wyobraża siebie jako pracownika odpowiadała na te same pytania [Ober-Domagalska: 2009: 95-114]. $\mathrm{Z}$ przeprowadzonych analiz wynika, że ma ona wyższe oczekiwania wobec pracowników ogólnie, niż wobec siebie w przyszłości.

W porównaniu do badanej przeze mnie młodzieży, dorośli badani w $2004 \mathrm{r}$. w ponad $40 \%$ uważają, że pracownik ma prawo odmówić wykonania pracy zleconej przez pracodawcę, jeżeli nie należy ona do obowiązków pracowniczych. Prawie 60\% ankietowanych uważa korzystanie ze sprzętu firmowego i materiałów biurowych należących do firmy w celach prywatnych za niewłaściwe. Za takie uważane jest również przez $66 \%$ dorabiane w czasie pełnienia obowiązków służbowych. Już jednak aż 73\% nie aprobuje pobierania dodatkowego nieuprawnionego wynagrodzenia za wykonanie pracy należącej do obowiązków pracownika. Aż 80\% badanych nie akceptuje spóźniania się do pracy. Panuje powszechny brak akceptacji do przychodzenia do pracy pod wpływem alkoholu. Powszechny jest również brak akceptacji dla przekazywania przełożonym informacji na temat błędów i nadużyć współpracowników [Lewandowska, Wenzel: 2004].

$\mathrm{Z}$ powyższych refleksji i analiz wynika, że następują zmiany w postawach młodzieży wobec pracy. Zgodnie z założeniami teorii modernizacji rozwój gospodarczy wpływa na zmianę owych postaw. Z koncentracji głównie na wartościach materialnych młodzież powoli zaczyna koncentrować się na wartościach 
autotelicznych. Nie bez znaczenia jest fakt, że tego rodzaju przemianę przewidywała już D. Walczak-Duraj oraz badana przez nią młodzież w roku 1993. Nie powinny jednak dziwić przemiany i brak stałości postaw młodzieży wobec pracy w czasach płynnej nowoczesności, która wymaga ciągłej zmiany.

\section{Bibliografia:}

Bauman Zygmunt, 1994, Dwa szkice o moralności ponowoczesnej, Instytut Kultury, Warszawa.

Bauman Zygmunt, 2006, Praca, konsumpcjonizm i nowi ubodzy, Wydawnictwo WAM, Kraków.

Boguszewski Rafał, 2006, Znaczenie pracy w życiu Polaków - CBOS - komunikat z badań.

Boguszewski Rafał, 2009, Moralność polaków po dwudziestu latach przemian, CBOS - raport z badań.

Boltanski Luc, Chiapello Eve, 2002, The New Spirit of Capitalism, Paper presented to the Conference on Europenist, Chicago.

Borkowski Tadeusz, 1999, Przemiany w etyce biznesu w Polsce przed i po 1989 roku, [w:] Dietl J., Gasparski W. (red.), Etyka biznesu, PWN, Warszawa.

Bronowicka Anna, 2009, Protestancka etyka pracy: porównanie przekonań studentów amerykańskich i polskich, [w:] Walczak-Duraj D. (red.) Wartości i postawy młodzieży polskiej, Wydawnictwo Uniwersytetu Łódzkiego, Łódź.

Duraj Danuta, 1993, Praca i jej kontekst społeczny w postawach młodzieży, Wydawnictwo UŁ, Łódź.

Falkowska Macieja, 1997, Praca - konieczność czy styl życia?, [w:] O stylach życia Polaków, CBOS, Warszawa.

Gasparski Wojciech, 2007, Wyktady z etyki biznesu, Wyd. Wpisz, Warszawa.

Inglehart Ronald, Welzel C., 2004, Modernization, Cultural Change and Democracy: The Human Development Sequence, Cambridge University Press, New York.

Jacher Władysław, Swadźba Urszula, 2008, Od tradycyjnego do komunikatywnego etosu pracy? Specyfika etosu pracy w Polsce, [w:] Mariański J., Smyczek L. (red.), Wartości, postawy i więzi moralne w zmieniajacym się społeczeństwie, Wydawnictwo WAM, Kraków.

Kiciński Krzysztof, 2002, Orientacje moralne spoteczeństwa polskiego, [w:] Mariański J. (red.), Kondycja moralna spoteczeństwa polskiego, Wydawnictwo WAM, Kraków.

Kopka Jolanta, 2008, Jednostka wobec moralności - subiektywna wizja przyszłości, [w:] Mariański J., Smyczek L. (red.), Wartości, postawy i więzi moralne w zmieniajacym się społeczeństwie, Wydawnictwo WAM, Kraków. 
Kopycińska Danuta, 1999, Wptyw aktualnej „wyceny” norm etycznych w Polsce na poglady przyszłych menedżerów, [w:] Dietl J., Gasparski W. (red.), Etyka biznesu, PWN, Warszawa.

Kwieciński Zbigniew, 1990, Młodziė̇ w sytuacji pogranicza, [w:] Sułek A., Więcławski W. (red.), Przełom i wyzwanie. Pamiętnik VIII Ogólnopolskiego Zjazdu Socjologicznego, Toruń 19-22 września.

Lewandowska Joanna, Wenzel Michał, 2004, Praca jako wartość - CBOS raport $\mathrm{z}$ badań.

Mariański Janusz, 2001, Kryzys moralny czy transformacja wartości?, Wydawnictwo KUL, Lublin.

Mariański Janusz, 2006, Socjologia moralności, Wydawnictwo KUL, Lublin.

Mariański Janusz, 2008, Spoteczeństwo i moralność. Studia katolickiej nauki społecznej i socjologii moralności, Wydawnictwo Diecezji Tarnowskiej, Tarnów 2008.

Norris Pippa, Inglehart Ronald, 2006, Sacrum i profanum. Religia i polityka na świecie, „NOMOS”, Kraków.

Novak Michael, 1993a, The Catholic Ethic and the Spirit of Capitalism, The Free Press, New York.

Novak Michael, 1993b, Chrześcijaństwo, kapitalizm i demokracja, [w:] Novak M., Rauscher A. SJ., Zięba M. OP (red.), Chrześcijaństwo, Demokracja, Kapitalizm, W drodze, Poznań.

Ober-Domagalska Barbara, 2008, Normy etyczne jakich powinien przestrzegać pracownik w opinii polskiej i norweskiej mtodzieży szkót średnich, „Kultura i Edukacja”, nr 4(68).

Ober-Domagalska Barbara, 2009, Obraz siebie jako przyszłego pracownika w opinii uczniów polskich $i$ norweskich szkót ponadgimnazjalnych, [w:] Walczak-Duraj D. (red.), Wartości i postawy młodzieży polskiej, Wydawnictwo Uniwersytetu Łódzkiego, Łódź.

Pawlina Krzysztof, 1998, Młodziė̇ przełomu wieków, Wyd. Sióstr Loretanek, Warszawa.

Sęk Arkadiusz, 1999, Plany, dązenia i aspiracje życiowe młodzieży, Komunikat $\mathrm{z}$ badań.

Sonnet Richard, 2006, Korozja charakteru. Osobiste konsekwencje pracy w nowym kapitalizmie, Warszawskie Wydawnictwo Literackie Muza SA, Warszawa.

Strzeszewski Michał, 2000, Praca zarobkowa i stosunek do pieniędzy młodzieży szkót ponadpodstawowych, Raport CBOS.

Świda-Ziemba Hanna, 2005, Młodzi w nowym świecie, Wydawnictwo Literackie, Kraków.

Świda-Ziemba Hanna, 2008, Paradoksy postaw etycznych młodzieży licealnej i studenckiej, [w:] Mariański J., Smyczek L. (red.), Wartości, postawy i wię- 
zi moralne $w$ zmieniajacym się społeczeństwie, Wydawnictwo WAM, Kraków.

Walczak-Duraj Danuta, 2005, Rola podmiotowości jednostki w kształtowaniu etycznego ładu ekonomicznego, [w:] Partycki S. (red.), Religia a gospodar$k a$, Tom I, Wydawnictwo KUL, Lublin.

Walczak-Duraj Danuta, 2008, Zróżnicowane podejścia do wartości moralnych w gospodarce wolnorynkowej, [w:] Mariański J., Smyczek L. (red.), Wartości, postawy $i$ więzi moralne $w$ zmieniajacym się społeczeństwie, Wydawnictwo WAM, Kraków.

Wciórka Bogna, 1998, Opinie Polaków o własnej pracy - CBOS - raport z badań.

Wciórka Bogna, 2009, Wakacje uczniów - wyjazdy na wypoczynek i praca zarobkowa - CBOS - raport z badań.

Weber Max, 1994, Etyka protestancka a duch kapitalizmu, Wydawnictwo Test, Lublin, http://www.egospodarka.pl/9324,Mlodzi-Polacy-bardziej-aktywni, $1,39,1$, o.html.

\section{CHANGES IN YOUTH ETHICAL ATTITUDES TO WORK}

\section{Summary}

The aim of this paper is to present changes in the attitudes of youth toward work over the past twenty years since the beginning of economic transformation in Poland. This review provides an analysis of selected articles. Due to variety of methodological approaches presented in choosen works this one can be treated as a kind of reflection on attitudes changes, however, it does not mean depriving of its scientific nature. In this article the author refers to the theoretical concepts proposed by Weber, Novak, Norris and Inglehart as well as reflects the changes in the values pointed by Mariański, Bauman and others. The author concludes that the economical changes in the course of transformation occur in young people's attitudes towards work. Work at the beginning of those changes was seen in pragmatic terms, as mean of providing income and ensure the basic needs of the individual. During the transformation it started to be seen in terms of autotelic. In conclusion, the author asks the question, if the attitude of young people have changed, or the way in which researchers pose their questions is affected as well.

Key words: youth, attitude, work, change values. 